\title{
The Impact of the European Union-Mercosur Association Agreement on gender inequality: A global South perspective
}

\author{
O impa acto do Acordo de Associação UE-Mercosul na desigualdade de gênero: uma perspectiva do sul global
}

DOI: https://doi.org/10.22456/2178-8839.113907

Carolina Pavese

ESPM, São Paulo, Brasil

carolpavese@gmail.com

\begin{abstract}
Globalization and trade liberalization have wide-ranging effects on employment, labor security, the environment, leading to processes with uneven gender consequences. Departing from a feminist approach, this study analyzes the potential impact of the latest EU-Mercosur Agreement on gender inequality. This research conducts a qualitative case- study focusing on the Mercosur, where women face already strong structural economic inequality. It argues that the adoption of a gender mainstreaming approach is essential for promotion of an interregional trade instrument that contributes to women's economic empowerment. The main findings reveal that the sectors affected by trade liberalization are sensitive to female participation. Yet, the analysis has shown that the draft text negotiated is blind the unequal opportunities that interregional trade liberalization poses to men and women, at least in the case of the Mercosur. As the document is pending ratification, it can be modified. Therefore, the EU and Mercosur still could adopt provisions that account for the uneven gender impact of the agreement, fostering gender equality in the global South.
\end{abstract}

Keywords: Trade liberalization; Gender inequality; EU-Mercosur agreement;

\section{Resumo}

Globalização e liberalização comercial têm consequências abrangentes para o emprego, segurança do trabalho, meio ambiente, levando a processos com impactos de gênero desiguais. Partindo de uma abordagem feminista, este artigo analisa o potencial impacto do último Acordo UE-Mercosul na desigualdade de gênero. Esta pesquisa realiza um estudo de caso qualitativo com foco no Mercosul, onde as mulheres enfrentam já fortes desigualdades econômicas estruturais. Este artigo argumenta que a adoção de uma abordagem de integração de gênero é essencial para a promoção de um instrumento comercial inter-regional que contribua com o empoderamento econômico das mulheres. As principais conclusões revelam que os setores afetados pela liberalização do comércio são sensíveis à participação feminina. Ainda assim, a análise mostrou que o texto negociado é cego no que tange às oportunidades e desafios que a liberalização do comércio inter-regional representa para homens e mulheres, pelo menos no caso do Mercosul. Como o documento está pendente de ratificação, ele pode ser modificado. Portanto, a UE e o Mercosul ainda poderiam adotar disposiçõe s que considerem o impacto desigual de gênero do acordo, fortalecendo a igualdade de gênero no Sul global.

Palavras-chave: Liberalização comercial; Desigualdade de gênero; Acordo UE-Mercosul; 


\section{Introduction}

According to feminist scholarship, gender inequality results from a system of gendered power relations, based on different norms and values of male and female responsibilities and roles (ELSON ET AL., 2007). The effects of trade liberalization on gender (in)equality are multifaceted, deriving from uneven access to capital, properties, labor markets, earnings, human capital, and correlated public policies, cultural biases and gender norms. They also vary according to the sectors at stake. When trade liberalization increases activities and improves working conditions in sectors with high female participation in the labor force, gender inequality might reduce. Conversely, when changes in trade pattern impact negatively these sectors, the gender gap is likely to widen up. As a result, there is clear correlation between trade liberalization an economic independence (FONTANA, 2009). Thus, "gender equality cannot be achieved without a change in a wide variety of policies, including, for example, labor market, fiscal and financial policies. Why then should we assume, it can be achieved in isolation from trade policy?” (VAN STAVEREN, 2007, p.257).

The primary objective of this research is to understand the gender dimension and the impact of the new EU Mercosur trade agreement on inequality, filling a gap in the literature. It argues that the adoption of a gender mainstreaming approach is essential for promotion of an interregional trade instrument that contributes to women's economic empowerment. The research adopts a qualitative case-study approach to explore the consequences of the agreement for women in the Mercosur.

Feminist theories are important tool for the analysis on the gender dimension of politics and provide the theoretical basis for this study. From the appraisal of main theoretical assumptions regarding the correlation between trade liberalization and gender inequality, it is possible to identify the elements that should be present in the empirical analysis of this correlation, applied to the study of the EU-Mercosur agreement. Primary sources, mainly statistics provided by international organizations on gender inequality in region, offer material to identify the degree of female economic empowerment in the Mercosur. Official documents from the negotiation process and the draft text of the agreement serve as the basis for the analysis of how (and if) gender issues are addressed by the new instrument for EU Mercosur trade relations. Crossing the literature review with the assessment of empirical material allows this research to produce an overall appraisal of the potential impacts of the interregional agreementfor gender inequalityin the Mercosur.

This article is divided into three main parts. The first provides a literature review on the feminist scholarship in international political economy, which allows understanding the correlation between globalization, trade liberalization, gender, and introduces the concept of gender mainstreaming. The second part presents a general overview of gender economic inequality within Mercosur countries. Finally, the third part analyses the text of the agreement, revealing how it failed to incorporate a gender mainstreaming approach. The final remarks wrap up the discussion delivered, concluding that the empirical evidence support the claim that trade policy and gender inequality are intertwined. By ignoring that, the EU and Mercosur have not jointly addressed the gender dimension of interregional trade in the new agreement.

\section{Globalization, Trade and Gender Equality}

The process of globalization has strong cultural, technological, political, social, and economic dimensions. It implies the strengthening of international exchanges between state and non-state actors. From an economic perspective, it has resulted in increasing flows of goods, services and investments, the accumulation of capital, and growth of multinationals. Shaped by the resurgence of neoliberalism, globalization has required structural adjustments that come at a cost. All these dynamics have uneven impact, both in terms of regions and social groups. Being it controversial in its nature, there is no consensus on the effects of globalization on gender inequality (BENERIA et al., 2010).

The arguments claiming a positive correlation between the two phenomena defend that globalization has lifted some of the constraints to inequality in three main ways. First, the diffusion of new information and communication 
technology has created more direct and indirect economic opportunities for women. Second, greater access to information has influenced a change in behavior patterns and expectations on the distinct role of women in society, strengthening the pursue of equality. Finally, inequality can damage the international image of a particular economy, which might increase domestic and external the pressure for the adoption of gender equality norms. Yet, globalization alone does not close the gap. It is crucial that governments adopt public policies that size the opportunities that globalization can create to promote gender parity (WORLD BANK, 2012).

One of the problems with this perspective is that it disregards the uneven regional impacts of globalization. As Sabaté (1999,p.24) posits:

Globalization is fundamentally understood as an economic process; However, its meaning should be broadened since, in practice, it constitutes the worldwide expansion of some forms of thought and culture - the Western one - that imply mercantilism, the exploitation of nature and, in fact, the marginalization of the most disadvantaged:women, the poor and non-Western cultures. It is therefore not surprising that globalization is exacerbating the deterioration of the environment as well as the living conditions of non-Western women (SABATÉ, 1999, p.24).

For Nagar et. Al. (2002) globalization impacts structures of domination and often results in the deepening of inequality patterns. Similarly, Peterson (2005) argues thatneoliberal globalization is a byproduct of geopolitical elites and serves the interest of powerful states and their transnational institutions. The control of different groups - and countriesover this process relies on an uneven rule, in which the rich are allowed to adopt strategic protectionist measures to compensate for their vulnerabilities, whereas developing economies have little capacity to act alike. In other words, the global North can strategically choose how to engage with globalization and benefit from it, but the global South is pushed to embrace neoliberalism fully. Consequently, economic globalization has led to further polarization and inequality between states and within different social groups.

Regarding polarization and regional distribution of wealth, Jaggar (2002) posits that the subordination of the global South to the North is the result of a historical process of colonial exploitation and violence. This colonial structure has been replaced with an economic system that perpetuated inequality and dependence. It deliberately undermines the attempts of developing countries to pursue their path towards prosperity and self-determination. This argument leads to the conclusion that the global North is indeed in long debt with the Southern part of the world, for their ongoing contributions to the wealth of the developed world.

Concerning increased inequalities amongst different social groups, Moghadam (1999) claims that capitalism is anything but blind to gender and ethnic politics. On the opposite. White and male individuals are the most favored ones by the forces of neoliberal economies - and they are commonly from the global North. One of the reasons is the fact that neoliberalism profits from labor exploitation on a global scale by operating mostly through large transnational corporations and some powerful stateinstitutions.

This exploitation of labor across different markets leads to what Standing (1999) defines as "feminization of employment". Hoskyns and Rai (2007), explain that this process could be understood as an increase in the participation of women in the job market. It can be also considered as the general precarization of labor standards and social protection, which subjects men to poorer working conditions equated to those commonly applied to women.

According to Berger (2009), globalization is characterized by the "mobility of capital" and "immobility of labor", preventing a tendency to global equalization of labor income. Workers compete indirectly through the incidence of their salaries on costs. This pressures for wage stagnation in the center and very different salary evolution in the periphery, depending on the dynamism of labor demand in each country. That is why Waylen (2006) emphasizes that the analysis of gender as a "constitutive of processes of globalization" requires abandoning the perception of the global (masculine) as opposed to the local (feminine). In this approach it is important to consider that shifts in the pattern of local activities can be the product of domestic social and economic changes, and not necessarily a direct consequence of globalization. Also, 
it is necessary to break with the distinction between public and private spheres that separate s productive from reproductive economies.

Most analyses and policy responses to inequality often ignore the role of women's unpaid labor in social reproduction (WAYLEN, 2006). And there is a purpose for that. The sexual division of work is a patriarchal separation necessary for the development of capitalism and the organization of political life, with men as the main protagonists of public life (VALDIVIESO, 2009). Equally concerning, the quantification of economic productivity only in monetary terms leads to an intentional depreciation of women's value and contribution to society. Expenditures on social policies that increase human welfare are often considered as “expenses” and financial burdens, ultimately delegitimating the demand of women for economic and political support for social services that w ould improve gender equality (FRASER; GORDON, 1997).

In addressing the negative impacts of neoliberal globalization on gender equality, the departing point is the assumption that "women" are not a homogeneous concept. Differences in terms of nationality, age, class, religion, ethnicity, sexuality, marital status, and motherhood define the way women are perceived in society, and, ultimately, the opportunities they must take part in economic, political and social spheres. Thus, the intersectional approach all ows understanding female economic empowerment in relation with local, national, and global contexts (JAGGAR, 2001).

For this reason, an intersectional approach is particularly important in Latin America, as the region has several ethnic groups that were discriminated against for centuries. In most of these populations, women face overlapping biases, for being a woman and for their ethnicity. Economic inequality leads tovaried interests, rights, and needs among women from different social classes. In common, however, all women are subjected to patriarchal societies that assign specific roles for them, often grounded on the exploitation of social and economic relations, in both private and public spheres (GIRON, 2009).

When considering trade liberalization, three important features common to this type of policy agenda are: increased imports, exports promotion, and market access provisions. Import liberalization has often a budgetary effect, as reduced tariffs lead to loss of government revenue. As a result, public spending tends to be reallocated away from social sectors - impacting women and children - the primary beneficiaries of these policies. At the same time, higher imports mean cheaper products available to domestic consumers, especially in the case of commodities, having a positive impact on the household budget. Yet, small producers face greater competition with foreign producers and, given that in many countries women rely on agriculture as a source of income, they are likely to be more penalized than men. Also, the incentives to cash crops tend to shift the gender division of labor as, traditionally, women manage food production and men cash crop production (exploiting female and male working force).

Export promotion may lead to the reallocation of resources to export-oriented sectors and influence the size and scope of business development. Often, larger producers and/or industries have the capacity (including financial resources) to adapt their activities to enter a foreign market. Smaller producers do not share the same potential gains from increased exports. How this process impacts gender inequality depends on whether local governments adopt gender -sensitive policies that guarantee the access of women toland, credit, and technology. Similarly, market access provisions impact the availability of technical assistance and marketing information. Thus, the gender sensitivity of domestic programs is important to ensure that women benefit from new economic opportunities (WILLIAMS, 2003). Once more, it is important to consider that not all women are impacted the same.

\section{Gender Mainstreaming in Trade Agreements}

Given that trade liberalization is capable of impacting gender relations in myriad ways, gender mainstreaming is the most adequate strategy to promote gender equality comprehensively. As a form of feminist politics and policy practice, the notion gender mainstreaming is grounded on feminist academic scholarship and the work of gender equality 
practitioners. As Walby (2005, p.454) claims, "it is a process that seeks to advance gender equality by revising all mainstream policy arenas. It is simultaneously intended as a way of improving the effectiveness of mainline policies by making visible the gendered nature of assumptions, processes and outcomes." When translated into practice, Hanna (2001:1) argues, gender mainstreaming involves "identifying and addressing relevant gender perspectives in data collection and research, analysis, legislation, policy development, development of projects and programs, as well as in training and other institutional development activities.”

The principle of gender mainstreaming dates to the 1970s and can be originally credited to development practitioners. More than two decades later, it was globally endorsed at the UN conference on women in Beijing, in 1995 (MEYER; PRUGL, 1999). Given its multidimensional nature and applicability, gender mainstreaming is conceived to be applied in all political arenas, including those that are not conventionally considered as gender sensitive areas. Thus, the Beijing Platform for Action (1995) explicitly refers to trade policies as an area of concern for gender mainstreaming. In paragraph 165 , the Platform advises governments to "seek to ensure that national policies related to international and regional trade agreements do not harm women's new and traditional economic activities". It recommends the "use gender-impact analyses in the development of macro and micro-economic and social policies to monitor such impact and restructure policies in cases where harmful impact occurs."

But governmental responses should not be designed only to address negative impact of trade policy (and agreements) on gender inequality. According to Women Watch (2011), an effective gender sensitive approach adopts norms and mechanisms that improve women's economic and social empowerment, and general wellbeing. Thus, explicit reference to gender equality in the text of trade agreements is an important strategy to strengthen political commitment and the availability of funding for gender-related programs of technical cooperation. These provisions are also important to ensure the monitoring of the gender impact of trade liberalization.

When gender perspectives are not taken into explicit account in the main text, an alternative is to produce ad hoc documents establishing the obligation to the parties to observe gender equality norms and recommendations that would be annex parts to the agreement. Finally, gender issues are also addressed in parallel activities and discussions surrounding the implementation of regional agreements or forums. Here it is worth reminding that gender $m$ ainstreaming is not just about agenda, but also incorporating gender equality into decision-making processes and implementation practices (WOMEN WATCH, 2011).

Putting forward some recommendations to promote gender mainstreaming in regional trade agreements, Williams (2002) suggests to departurefrom the assumption that gender is a cross -cutting issue. The main strategies to be adopted are the following: a) regional trade agreements should provide an opportunity for the parties to share experiences in integrating gender into different policy areas, as well as promoting a more gender-balanced decision-making process; b) gender impact assessment and strategies should be promoted in all stages of negotiation and implementation of the agreement; c) development and adoption of a coherent policy and institutional framework for gender mainstreaming, d) prioritization of the collection of sex-disaggregated data; e) support the creation and/or activities of independent women's leadership and professional organizations; f) conduct research on women in small and micro business enterprises; g) improve human resources development of female working force. Nevertheless, as Van Staveren (2007) claims, recommendations of international organizations need to be turned into concre te policy measures to have an impact. So far, the response has been limited and varies depending on the agreement at stake.

Taking these considerations into account, the next sessions present an overview of gender inequality in Mercosur. Following, the article analyses how - and whether-gender mainstreaming has been considered in the text of the EU-Mercosur Association Agreement. 


\section{"Where are the women"? Gender economic inequality in Mercosur}

Latin America features among the most unequal societies in the world in terms of wealth and income distribution. Mercosur is no exception. Analyzing the GINI index for measuring inequality, all four members of the bloc have a coefficient of around 40 (in which zero would represent full equality). Brazil, the largest economyin the region, is also the most unequal country, scoring 53.4 points in 2019 (WORLD BANK, 2021).

Comparing 156 countries across different indicators, the Global Gender Gap Report 2021 reveals the effect of the overall inequality in the Mercosur on gender. In the overall rank, Argentina performed significantly better than the three other countries, occupying the $35^{\text {th }}$ global position. Uruguay and Paraguay are in $85^{\text {th }}$ and $86^{\text {th }}$ place, respectively, whereas Brazil is in the $95^{\text {th }}$ position. In terms of economic participation and opportunity, an indicator that considers labor force participation, wage equality, and type of work activity, the picture is no better. The best performance is that of Uruguay (76), followed by Paraguay (86) and Brazil (89), with Argentina recording a very low score, ranking 103 out of 156 countries surveyed. Overall, economic participation and political empowerment are the two indicators in which Mercosur countries perform the worst (WORLD ECONOMIC FORUM, 2021).

These data reveal that there is strong economic inequality in the region, consequently, placing women in a more vulnerable position when it comes to shifts in economic and trade policies and landsca pe. Given that theimpact of the new EU-Mercosur Association Agreement varies according to the sector and considering that women participate in different economic activities unevenly, it is important to understand the distribution of economic activities across the bloc, to identify the possible effects of the agreement on gender inequality.

According to UNCTAD (2018), although Mercosur countries feature among the largest global exporters of commodities, agriculture is the smallest sector in all four economies. In Argentina, Brazil, and Uruguay, agriculture contributed to 7.6, 5.5, and 6.8 percent of the economy, respectively, being a stronger sector in Paraguay, where it corresponded to 20 percent of GDP, in 2017. In contrast, in that same year, services accounted for the largest share of the economy in all countries: $49.7 \%$ in Paraguay, 64.4\% in Uruguay, 65.8\% in Argentina, and 73.3\% in Brazil. Regarding industry, it was the second most important sector in the economies of the bloc. Paraguayleads the rank (30.3\%), followed by Uruguay (28.8\%), Argentina (26.7\%), and Brazil (21.2\%).

Since liberalization impacts different economic structures, the opening of the economies and theincentives of the global market for the exports of agricultural goods have led to a deindustrialization processin the region. From 1991, when Mercosur was created, to 2017, the share of manufacturing in GDP almost halved, going from an average of $25 \%$ to less than $13 \%$ across the four economies. This early deindustrialization is also seen as contributing to the "defeminization" of industrial employment.

The proportion of employed women in the industry has decreased in line with regional integration in countries such as Uruguay, Paraguay, and Argentina. Formal employment in the industry is therefore also predominantly male. The difference is in the service sector, in which regional integration and trade liberalization have been matched by an increase in female participation in the labor market. This is even more significant when we consider that the tertiary sector is the largest source of employment in all four Mercosur countries. and constitutes the largest share of GDP However, women and men tend to be employed in different types of activities in this sector, occupying mostly functions re lated to the areas of education, social services, and health care.

In the case of agriculture, a key sector for the region, there was a recent inversion of occupation in the sector, with men predominantly assuming the largest share of jobs, from the point of view of formal employment, highlighting here the difficulty of obtaining statistics that reflect with this panorama, especially since women tend to remain more informal - and precarious - than men (UNCTAD, 2018).

The numbers prove these arguments. According to the International Labor Organization- ILO (2017), the employment rate for people ages 15 or older in the four Mercosur countries was 53,3\% for women and 76,55\% for men, on 
average, in 2017. Data provided by UNCTAD (2018), explore the effect of regional integration on women's participation in economic activities between 1998 and 2017. Assessing the results, it is interesting to observe that the impact varied across the four founding members of Mercosur. Regarding industry, Brazil is the only country in which there was a smallincrease in female employment in the sector (from 9,4\% to 10,8\%), while the share of women shrunk in Argentina, Uruguay, and Paraguay. In agriculture, there has been an increase in women's participation in the sector in Uruguay and Argentina, whereas numbers remained steady in Paraguay. Interestingly, in the case of Brazil, there was a sharp decrease, from 19\% to less than 5\%, comparing 1998 to 2017. In all these cases, employment in the sector remains male -dominant (UNCTAD, 2018).

Thus, given that the trade liberalization agreements directly impact the economic structure of the markets involved, they almost inevitably carry a gender dimension. The way to convert these agreements into an opportunity to improve equality depends on the extent to which policymakers are not gender blind and instead adopt a gender mainstreaming approach to negotiations, that ultimately lead to a gender-balanced agreement.

The next session presents an overall analysis of the new EU-Mercosur Association Agreement and scrutinizes if (and how) gender mainstreaming features in the draft text that is now subjected to ratification.

\section{The EU - Mercosur Association Agreement}

EU-Mercosur relations were formalized with the celebration of an Interregional Framework Agreement for Cooperation, in 1995, entering into force in 1999 and still providing the current legal basis for their relationship. Already in 1995, leaders from Mercosur and the EU met in Rio de Janeiro and decided to promote a new interregional agreementon trade liberalization. On the occasion, the parties established that all sectors should be covered by the deal, observing the principle of single undertaking. Negotiations were officially launched in 2000, but, after 13 meetings of the Bi-regional Negotiations Committee (BNC), they came to a halt, in 2004.

In terms of agenda, the suspension of negotiations was due to discrepancies regarding the exchange of offers. Whereas Mercosur was not satisfied with the treatment of tariff quotas on agriculture proposed by the EU, the Europeans were not pleased by the concessions on services and public procurement that they would be granted. Furthermore,the EU was conditioning the negotiation to the conclusion of the Doha Round negotiations of the World Trade Organization which is still pending. Another important externality thateased theEU's interest in reaching an agreement was the failure of negotiations of the Free Trade Area of the Americas (FTAA), which posed direct competition with the United States for the preferential market access within South America (ARANA, 2017).

In addition, the international financial crisis of 2008, the EU enlargement process to central and e astern Europe, also negatively impacted the interest on interregional trade liberalization. Moreover, both regions experienced political changes and the redefinition (crisis) of their respective regional integration processes. Yet, at the same time competition with China for market access in Latin America and exports decrease to the continent mobilized greater domestic interest in the EU to reopen negotiations with Mercosur (SANAHUJA; RODRIGUEZ, 2019).

From the Mercosur's perspective, deteriorating economic situation and political instability in the member states were putting its own process of regional integration at stake. With strong intergovernmental nature, Mercosur relies heavily on domestic support to develop. By early 2004, a wave of left-wing governments was showing certain commitment to reinforcing integration and strengthening the bloc's relevance in international trade. But that feeling did not last long. Mercosur was emerged on its own crises. Furthermore, slow progress in negotiations, the revisiting of the benefits of interregionalism, and changing perceptions of the balance of power within and between regions combined triggered the poor interest in reaching an agreement with the EU at all costs (DOCTOR, 2007). Yet not everything was lost.

During the Madrid Summit, in 2010, the parties decided to relaunch the discussions of what would be an “Association Agreement” structured around three pillars (or chapters): political dialogue, cooperation, and trade. 
Negotiations resumed without the controversial exchanges of offers, which was only unlocked when Brazil and Argentina elected neoliberal governments, in 2016. Adopting a new approach to the agreement, the two countries were no longer insisting so emphatically on a balanced deal thatwould ensure the adoption of commercial defense instruments to account for asymmetries. Instead, the new administrations advocated for what they considered "an intelligent insertion in the world"; under this view, a free trade agreement with the EU would be important to decrease growing interdependence with China.

Exchanges of offers began in May 2016, speeding up from January 2019, when President Jair Bolsonaro took office in Brasilia. Six months later, the EU and Mercosur announced the conclusion of 20 years of negotiations of the trade part of the agreement. (GHIOTTO; ECHAIDE, 2019). One year later,in June 2020, the European Union and Mercosur concluded negotiations on the Political Dialogue and Cooperation part as well as on the Preamble, and the General, Institutional, and Final Provisions of the EU-Mercosur Association Agreement (EEAS, 2020) The full text of the agreement is ready, yet it is far from entering into force. The deal is pending on a length and controversial ratification process that engages member states from both regional organizations.

\section{The Agreement at a glance}

Lacking democratic accountability, the full draft text of the EU-Mercosur Association Agreement has not been made public, as only the trade part of this three-pillar agreement was published by the European Commission. In 2019, Greenpeace obtained a copy of the full document and leaked it online. The political and cooperation chapter (encompassing the first two pillars of the Agreement), is composed of 49 articles. There, the parties agree to e stablish a political agenda for dialogue, promote interregional cooperation in areas of common interest and make efforts to coordinate their positions to undertake joint initiatives in the appropriate international fora. The agenda for political cooperation is divided into 19 areas, including strengthening of democracy and the rule of law, disarmament, and non proliferation of weapons of mass destruction, promotion of human rights and sustainable development, peace, stability and security, and the promotion of gender equality, among other issues (GREENPEACE, 2019).

As mentioned at the outset, the draft text of the third pillar, "trade", is the only one available for public consultation, yet that happened after negotiations were concluded. As the document is pending ratification, it is still subjected to change. Therefore, the version available for consultation is a summary of the agreement with nolegal value. According to the document issued by DG Trade (2019a), the agreement entails 17 chapters, addressing a broad range of issues, including trade in goods, sanitary and phytosanitary measures, services and establishment, public procurement, competition, subsidies, state-owned enterprises, intellectual property rights, including geographical indications, trade, and sustainable development, among others.

Regarding trade in goods, the agreement has a strong emphasis on trade liberalization from both partners. In a transition period of up to 10 years, the EU should open $92 \%$ of its imports from Mercosur, whereas the latter has accepted to liberalize $91 \%$ of its imports from the European market. In agriculture, a sensitive area of negotiations, the EU agreed to liberalize $82 \%$ of agriculture imports, with specific conditions being attached to most sensitive products. Beef, poultry, ethanol, pig meat, corn, honey, and rice are protected with partial liberalization mechanisms, including tariff-rate quotas. On the other hand, Mercosur granted the EU free access to products such as wine and non-alcoholic beverages, chocolates, olive oil, pig meat, and fresh and canned fruits. Reciprocal tariff-quotas should apply to cheese, milk powder, and baby formula.

In terms of industrial goods, the EU will wave all duties on $100 \%$ of imports, whereas tariffs on $90 \%$ of products exported to Mercosur will be eliminated, over a transition period of 10 years. Here it is worth point out the fact that the EU will gain relevant access to sensitive manufactured goods, like cars and parts, machinery, and chemicals, although special conditions apply. 
The agreement determines that the parties will remove "unnecessary" discretionary obstacles to facilitate services exports and the establishment of EU firms in Mercosur from sectors such as financial services, transport, communication, financial services, e-commerce, postal and courier services, and maritime activities. Public procurement, another sensitive area, will be also subjected toliberalization, with EU companies being able to compete on equal footing as a national business in Mercosur. No other international market has been granted this right to be free to bid in public contracts before. Another important aspect is labor mobility, with provisions facilitating the movement of professionals "for business purposes" (DG TRADE, 2019a).

Chapter 14, entitled "Trade and Sustainable Development (TSD)", sets up social and environmental provisions, distributed across 18 articles. The parties agreed to not lower the standards in these agendas to attract trade and investments. Regarding labor rights, they agreed to respect and promote the Constitution, conventions, and other regulations adopted by the International Labor Organization (ILO), including the abolishment of forced labor, child labor, and any kind of discrimination. The promotion of decent work (including health and safety regulations, fair earning, regulated working hours, and other relevant working conditions) is another commitment adopted by the parties. Any infringement to the labor rights referred to in the chapter should be dealt with by dom estic judicial and administrative institutions.

In terms of the environment, each Party reaffirms its commitments to promote and effectively implement, multilateral environmental agreements (MEAs), protocols, and their amendments, including the Paris Agre ement. Specific articles cover climate change, biodiversity, fisheries and aquaculture, sustainable management of forests, investmentrelated initiatives addressing sustainable development, and management of supply chain. To oversee and facilitate the implementation of the chapter, article 14 establishes the creation of a sub-committee on trade and sustainable development and contact points.

The chapter is subject to a specific dispute settlement procedure, that differs from the one that covers all other chapters in the trade agreement. Upon the specific instrument created, a complaint concerning non-compliance is first considered informal government consultations. If the situation is not resolved, then an independent panel of experts can be requested to examine the matter and make recommendations, that should be made public (DG TRADE, 2019b). Notably, there is no binding, independent dispute resolution mechanism in the Agreement in respect of sustainability issues. Equally concerning, there is no provision allowing the civil society to act against the potential violation of sustainability standards, eventually using the dispute settlement mechanism created.

\section{The Lack of Gender Mainstreaming in the EU Mercosur Agreement}

As demonstrated above, the new Association Agreement is a comprehensive accord that aims at promoting cooperation in various areas, not only trade. Analyzing the copy of the draft text leaked by Greenpeace (2019) it is possible to assess the degree of emphasis placed on gender issues. In the first pillar of the agreement, one of the objectives of the "Political Dialogue" is to promote "gender equality, respect for the rights of all women and girls, with an emphasis on the gender perspective, and to address discrimination and violence based on sexual orientation, in accordance with the internal legislation of each country". That is the sole mention of gender in the first pillar.

In the "Cooperation" pillar, gender is evoked on more occasions. The first is in the section "Cooperation on democratic principles, human rights, the rule of law and international peace and security". In this part there is an item entitled "gender equality, peace, and security", which establishes that the parties would work together to: a) promote greater participation by women in politics, education, and the labor market; b) combating all forms of violence, strengthening women's rights; c) support for the development and implementation of the national plans provided for by Security Council Resolution 1325; d) promote effective "gender mainstreaming"; and e) collaborate with relevant UN bodies and other international organizations. Gender is also mention in other items on the cooperation agenda, such as 
labor policies and migration, and, with a little more emphasis, in the item on sustainability (GREENPEACE, 2019). Despite the mention of several issues of gender agenda, neither one of the two pillars provide details on how the parties aim at achieving these objectives.

In the third and most controversial pillar of the agreement, "Trade", the only mention of gender is in the chapter "Trade and Development". In its article 13 ("working together in developing trade”), the text-only signals that the parties will seek the interrelationship between skills development and gender equality (DG TRADE, 2019a). Again, no detail is provided.

Recalling how the literature suggests approaching gender inequality in regional trade agreements, the AA is flawed in many aspects. Overall, the draft text of the agreement does not lay out effective strategies measures to promote gender equality, including a comprehensive institutional framework for gender mainstreaming. Also, it does not make explicit mention of a gender-balanced decision-making process or to create channels for fostering the participation of civil society organizations led by women in the implementation and monitoring of the agreement.

Nevertheless, one of the recommendations to achieve gender mainstreaming posited by Williams (2002) was partially contemplate. Since the resuming of negotiations, in the mid-2000s, the EU has produced Sustainability Impact Assessment (SIA) periodically. The main objective of these studies is to provide an instrument for assessing the potential economic, social, human rights, and environmental impact of agreementwhile they are still in negotiation. Unfortunately, Mercosur did not adopt the same practice. Therefore, this paper relies on the SIA on Mercosur produced for the European Commission, in 2009. Even if it does not dedicate a separate chapter to gender, it mentions the issue on several occasions. Regarding economic empowerment, the SIA report assessed that:

the main concerns about the effects of trade liberalization in agriculture on the well-being of women and gender relations are related to the potential deepening of the 'feminization of productive assets', unequal employment opportunities and working conditions, and poverty. This can result in differentiated access and control of land and other different effects in terms of food security. [...] Competition between farmers for new arable land is expected to increase land prices and also land conflicts in areas where land tenure is weak. Small farmers can be the losers in this process, including women. Adverse gender impacts can arise through the loss of traditional livelihoods and limited opportunities for women in the formal sector (EUROPEAN COMMISSION, 2009).

The 2020 version of the Sustainable Impact Assessment, the last of one of its kind, did not focus on Mercosur but included the bloc in its analysis. The conclusion was like the previous report, as it argues for "the recognition that there is a latent risk that the agreement in some respects will accentuate inequalities in the Mercosur countries, especially affecting women whowork in the agricultural sector or are in conditions of greater informality or with lower income" (EUROPEAN COMMISSION, 2020).

Despite the constatation that the Agreement carries potential impact to widen gender economic inequality in Mercosur, the instrument does not provide guidelines or measures to avoid this effect. Therefore, neither the official text of the agreement nor the SIA reports contemplate gender mainstreaming in its overarching nature. Additionally, as Hoffmann (2014, p.134) claims, neither one of the parties positioned itself as an "exporter of 'gender mainstreaming and other (economic) interests prevail over gender. The interregional level, so far, does not constitute a centrallevel of diffu sion and spread of gender norms". Considering where and how women take part in paid economic activity and the broad sectoral impact of the Agreement in the economies of the bloc, the EU - Mercosur Association Agreement poses a potential threat to gender economic equality in the four countries from the global South.

\section{Conclusion}

This article sought to analyze the possible gendered impacts of the EU-Mercosur Agreement, especially when it concerns economic empowerment. In as much as mainstream literature tend to be gender blind, there is no such thing as 
gender neutrality. Yet the review of the literature conducted stressed the importance of paying attention to the uneven effects of economic activities on gender. As the feminist scholars claims, economic and trade policies and practices reflect and reinforce unequal power relations in which our societies are structured. In this sense, the often-endorsed "gender neutral" approach to trade liberalization is strongly bias towards the normalization of inequality, privileging mostly white men, specially from the global North. In other words, when it comes to gender (and other inequalities), there is no neutrality. Omission serves the purpose of perpetuating inequality. The implementation of a gender mainstreaming approach is an effective strategy to alter this course of action, turning trade and economic policies into instruments that benefitwomen.

The theoretical debate that this article engaged with, allowed this research to hold the argument that the EU Mercosur agreement carries an unavoidable uneven gender impact. The literature also backed the claim that the conclusion on whether this interregional deal hinders, or harms women's economic empowerment depends on how the parties addressed the gender dimension of their new trade instrument.

To explore the specific case study of Mercosur, this research considered the assumption that "women" cannot be dealt as a homogeneous group. Consequences of trade liberalization on gender inequality vary according to the patterns of female participation in economic activities that are affected by the agreement. Assessing gender economic inequality in the four Mercosur founding members, this research identified strong evidence to support the claim that economic empowermentremains one of the Achilles heels for gender equality in the region. Overall, a significant share of women in the global South participates mostly in the informal economy in fragile conditions. Consequently, they are deprived of social and health protection, as these workers or their employers seldom pay taxes and normally operate below the radar of labor and safety standards. Interestingly, the data provided reveal that the economic liberalization and regionalism processes that took place in the region over the past decades did not have a positive impact on inequality. On the contrary, the economic empowerment gap widened up. Against this background, this research demonstrated that women in the Mercosur are more vulnerable than men to the effects of a trade agreement with the EU.

As the literature proposes, the promotion of a gender mainstreaming approach to trade negotiations would ideally establish coordinated mechanisms to address the gender dimensions of an agreement. At least in terms of joint efforts, this study did not find enough evidence to consider that this was the approach of the EU and Brazil to negotiations.

Analyzing the draft text, it can be claimed that, even if the Association Agreement incorporates gender equality among the objectives of the first two pillars (political and cooperation), it does not provide details on how to achieve it. Regarding the "trade pillar", the mention to observe ILO standards in the chapter on sustainability (chapter 14), without explicit mention of gender, is a source of concern. The Sustainable Impact Assessments (SIAs) mention gender minimally, missing an important opportunity to highlight the consequences of the agreement to different populations. Overall, nor the agreement nor the SIA have adopted a robust gender mainstream approach and both instrumentsignored the necessity of an intersectional perspective to trade liberalization and its consequences.

Considering the structural roots of gender inequality and how it manifests so strongly in Mercosur economies, the omission of a solid gender dimension in the approach to trade cooperation is not at all surprising, but it is equally worrying. It is very problematic that Mercosur did not publish any SIA report over the course of two decades of negotiations. If these flaws are not amended in the discussion leading to the ratification process, the EU-Mercosur Association Agreement might create incentives for new patterns of inequalities, undermining the already difficult prospects of achieving gender equality in the global South. Nevertheless, the fact that the agreement still has to endure a lengthy and controversial ratification process before it can enter into force provides a window of opportunity for the EU and Mercosur to address the gender dimensions of the new deal. For that, the parties should commit to promote gender impact assessments, prioritize of the collection of sex-disaggregated data, share experience and best practices in integrating gender into different policy areas and engage women in decision-making processes. Combined, these 
strategies will allow the EU and Mercosur to develop and implement coherent policies and interregional institutional framework for gender-mainstreaming. Finally, even if parties have the autonomy to adopt their own approach to the issue, it is important that actions as coordinated. Interregionalism is based on the voluntary decision to increase interdependence; shifts in the pattern of inequality in one party is likely to affect the other. Future research addressing the impact of the agreement in EU would allow an interesting analysis of the correlation between gender inequality across the two regions.

\section{References}

ARANA, Aranza Gomez. The European Union's Policy Towards Mercosur: Responsive Not Strategic. Manchester University Press, 2017.

The Beijing Declaration and the Platform for Action. Fourth World Conference on Women, Beijing, China, 4 -15 September. New York: Dept. of Public Information, United Nations, 1995.

BENERIA, Lourdes. Gender and the global economy. Cornell: Cornell University,1998.

BENERIA, Lourdes. Et. Al. Introduction: Globalization and Gender. Feminist Economics, vol 6, n. 3, pp.vii-xviii, 2000.

BERGER, Susan. Troubleshooting Economic Narratives In: A KNAPEN, Hemerijck;VAN DOOME (eds.) Aftershocks: Economic Crisis and Institutional Choices, Amsterdam: University of Amsterdam Press, 2009.

DG TRADE. New EU-Mercosur trade agreement:The agreement in principle Brussels, 1 July 2019a. Available at: https://trade.ec.europa.eu/doclib/docs/2019/june/tradoc_157964.pdf (last access: 15 April 2021).

DG TRADE. Text of the EU Mercosur Agreement: Trade and sustainable development. Official Document, 12 July 2019 b. Available. at: https://rade.ec.europa.eu/doclib/docs/2019/july/tradoc_158166.\%20Trade\%20and\%20Sustainable\%20Development.pdf (last access: 15 April 2021)

DOCTOR, Mahrukh. Why Bother with Inter-Regionalism? Negotiations for a European Union-Mercosur Agreement. Journal of Common Market Studies, vol 45, n.2, pp.281-314, 2007.

EEAS. EU-Mercosur Association Agreement: conclusion of negotiations on the Political Dialogue and Cooperation pillar. News stories, 02 July 2020. Available at: https://eeas.europa.eu/headquarters/headquarters-homepage/81950/eu-mercosur-associationagreement-conclusion-negotiations-political-dialogue-and-cooperation_en (last access: 15 April 2021).

ELSON, Diane Et.Al. Introduction: Why a feminist economics of trade? In: VAN STAVEREN, Irene Et. Al. (eds.) The feminist economics of trade. London: Routledge, 2007.

EUROPEAN COMMISSION. Sustainability Impact Assessment in Support of the Association Agreement Negotiations between the European Union and Mercosur. Luxembourg: Publications Office of the European Union, 2020.

FONTANA, Marzia. Gender Justice in Trade Policy: The Gender Effects of Economic Partnership Agreements. London: One World Action, 2009.

FRASER, Nancy, GORDON, Linda. A genealogy of "dependency”; tracing a keyword of the US welfare state.I n: Fraser, Nancy (ed.) Justice interruptus: Critical reflections on the "postsocialist” condition, ed. Nancy Fraser. New York: Routledge, 1997.

GIRON, Alicia (ed.). Géneroy globabización. Buenos Aires: Consejo Latinoamericano de Ciencias Sociales - CLACSO,2009.

GHIOTTO, Luciana; ECHAIDE, Javier. Analysis of the agreement between the EU and Mercosur. Buenos Aires. Brussels, December 2019. Available at: https://www.annacavazzini.eu/wp-content/uploads/2020/01/Study-on-the-EU-Mercosur-agreement-09.01.20201.pdf (last access: 05 April 2021).

HANNAN, Carolyn. The United Nations commitment to gender mainstreaming: a global strategy for promoting equality between women and men. Paper prepared for the 2001 ODCCP Field Representatives Seminar. Office of the Special Adviser on Gender Issues and Advancement of Women, New York, 2001.

HOFFMAN, Andrea R. Gender mainstreaming in Mercosur and Mercosur-EU trade relations. In: van der Vleuten, A.,Et.Al. (eds), Gender Equality Norms in Regional Governance - Transnational Dynamics in Europe, South America and Southern Africa. New York: Palgrave MacMillan, 2014.

HOSKYNS, Catherine; RAI, Shirin M. Recasting the Global Political Economy: Counting Women's Unpaid Work. New Political Economy, vol 12, n. 3, pp. 297-317,2007.

INTERNATIONAL LABOR ORGANIZATION, World Employment Social Outlook. Trends for Women. Geneva: ILO, 2017 
JAGGAR, Alison. Is Globalization Good for Women? Comparative Literature, vol. 53, no. 4, pp. 298 -314, 2001.

MARCHAND, Marianne; RUNYAN, Anne S. Gender and Global Restructuring, Sighting, Sites and Resistances. London and New York: Routledge, 2011.

MEYER, Mary; PRUGL, Elizabeth (eds). Gender Politics in Global Governance. Lanham: Rowman and Littlefield,1999.

NAGAR, Richa Et.Al. Locating Globalization: Feminist (Re)readings of the Subjects and Spaces of Globalization. Economic Geography, vol. 78, No. 3, pp. 257-284,2002.

TRUE, Jacquie. Trading-Off Gender Equality for Global Europe? The European Union and Free Tra de Agreements. European foreign affairs review, vol. 14, n.5, pp.723-742, 2002.

PETERSON, Spike. V. How (the meaning of) gender matters in political economy. New Political Economy, vol 10, n.4, pp. 499-521, 2005.

POMATTO, Valentina. Gender, trade, and employment. 2019. Available at: https:/europa.eu/capacity4dev/publicgender/minisite/gender-trade-and-employment (last access: 30 March 2021).

SABATÉ, Ana. Género, medio ambiente y globalización: una perspectiva desde el sur In: VILLOTA, Paloma. (ed.) Globalización y género. Madrid: Síntesis, 1999.

SANAHUJA,José Antonio; RODRIGUEZ,Jorge Damián. Veinte años de negociaciones Unión Europea-Mercosur: Del interregionalismo a la crisis de la globalización. Documentos de Trabajon. 13, Madri: Fundación Carolina, 2019.

STANDING, Guy. Global Feminization Through Flexible Labor. World Development, vol. 17, n.7, pp.1077-95,1999.

UNCTAD. Teaching Material on trade and gender volume 1: Unfolding the Links. (UNCTAD/DITC/2018/2). Geneva: United Nations Conference on Trade and Development, 2018.

VAN STAVEREN, Irene. Genders indicators for monitoring trade agreements. In: VAN STAVEREN, Irene (et. Al.) (eds.) The feminist economics of Trade. Oxon: Routledge, 2007.

WALBY, Sylvia. Introduction: Comparative gender mainstre aming in a global era. International Feminist Journal of Politics, vol 7, n. 4, pp. 453-47,2005.

WAYLEN, Georgina. You Still Don't Understand:Why Troubled Engagements Continue between Feminists and (Critical) IPE. Review of International Studies, vol. 32, n.1, pp. 145-164, 2006.

WILliAMS, Mariama. Gender Mainstreaming in the Multilateral Trading System. A handbook for policymakers and other stakeholders. London: Commonwealth Secretariat. 2003.

WOMEN WATCH. Gender Equality and Trade Policy. United Nations Inter-Agency Network on Women and Gender Equality (IANWGE), Resource Paper, 2011.

WORLD BANK. Gender Equality and Development. World Development Report. 2012. Available at: https://elibrary.worldbank.org/doi/pdf/10.1596/9780821388105_ch6 (last access: 12 July 2021).

WORLD BANK. Gini Index (World Bank estimate). 2021. Available at:

https://data.worldbank.org/indicator/SI.POV.GINI?end=2019\&start=1967\&view=chart (last access: 10 April 2021).

\begin{tabular}{ll} 
Authors' Contributor Roles \\
\hline Carolina Pavese: & $\begin{array}{l}\text { Conceptualization; Methodology; Data Curation; Project Administration; Investigation; Supervision; Writing (Original Draft } \\
\text { Preparation); Writing (Review \& Editing); }\end{array}$
\end{tabular}

Information provided by the authors according to the Taxonomy of author contributions (CRediT) 